\title{
Aerobic and Anoxic Growth and Nitrate Removal Capacity of a Marine Denitrifying Bacterium Isolated from a Recirculation Aquaculture System
}

\author{
Maria-Teresa Borges $^{1,2}$, André Sousa ${ }^{1,2}$, Paolo De Marco $^{3}$, Ana Matos ${ }^{1,2}$, Petra Hönigová ${ }^{4}$ \\ and Paula M. L. Castro ${ }^{4}$
}

(1) Departamento de Zoologia-Antropologia, Faculdade de Ciências da Universidade do Porto, Praça Gomes Teixeira, 4099-002, Porto, Portugal

(2) Centro Interdisciplinar de Investigação Marinha e Ambiental (CIIMAR), Rua dos Bragas 177, 4050-123, Porto, Portugal

(3) Instituto de Biologia Molecular e Celular (IBMC), Universidade do Porto, Rua Campo Alegre 823, 4150-180, Porto, Portugal

(4) Escola Superior de Biotecnologia, Universidade Católica Portuguesa, Rua Dr. A. Bernardino de Almeida, 4200-072, Porto, Portugal

\section{Abstract}

Bacterial biofilters used in marine recirculation aquaculture systems need improvements to enhance nitrogen removal efficiency. Relatively little is known about biofilter autochthonous population structure and function. The present study was aimed at isolating and characterizing an autochthonous denitrifying bacterium from a marine biofilter installed at a recirculation aquaculture system. Colonization of four different media in a marine fish farm was followed by isolation of various denitrifying strains and molecular classification of the most promising one, strain T2, as a novel member of the Pseudomonas fluorescens cluster. This strain exhibits high metabolic versatility regarding $\mathrm{N}$ and $\mathrm{C}$ source utilization and environmental conditions for growth. It removed nitrate through aerobic assimilatory metabolism at a specific rate of $116.2 \mathrm{mg} \mathrm{NO}_{3}-\mathrm{N} \mathrm{g} \mathrm{dw}^{-1} \mathrm{~h}^{-1}$. Dissimilatory $\mathrm{NO}_{3}-\mathrm{N}$ removal was observed under oxic conditions at a limited rate, where transient $\mathrm{NO}_{2}-\mathrm{N}$ formed represented $22 \%\left(0.17 \mathrm{mg} \mathrm{L}^{-1}\right)$ of the maximum transient $\mathrm{NO}_{2}-\mathrm{N}$ observed under anoxic conditions. Dissimilatory $\mathrm{NO}_{3}-\mathrm{N}$ removal under anoxic conditions occurred at a specific rate of $53.5 \mathrm{mg} \mathrm{NO}_{3}-\mathrm{N} \mathrm{g} \mathrm{dw}^{-1} \mathrm{~h}^{-1}$. The isolated denitrifying strain was able to colonize different materials, such as granular activated carbon (GAC), Filtralite and Bioflow plastic rings, which allow the development of a prototype bioreactor for strain characterization under dynamic conditions and mimicking fish-farm operating conditions.

Correspondence to: Maria-Teresa Borges; E-mail: mtborges@fc.up.pt
Introduction

Intensive fish farm effluents are enriched with dissolved nutrients resulting from fish excretion and feed losses [34]. Effluent treatment is mandatory facing EU regulations and water reuse needs in recirculation aquaculture facilities $[5,6]$. Current technology is based on biofiltration [42] integrated in a complex treatment loop including suspended solids separation, dissolved gases $\left(\mathrm{O}_{2}\right.$ and $\left.\mathrm{CO}_{2}\right)$ control, nitrification, and disinfection [5]. Although not as toxic for fish as ammonia or nitrite, but directly affecting their immune system [14], nitrate accumulates in closed systems and must be removed. Nevertheless, denitrification is not widely employed because of technological and economical constraints, deriving from denitrifying filters still needing further developments, especially for seawater applications [44] where ultraoligotrophic water quality is required [15]. Microbial cultures for denitrification reactors are commonly derived from freshwater-activated sludge, followed by an acclimation period. This results in high bioreactor colonization time, low performance on the long term, and high susceptibility to environmental stress. Available operation data show a high variability in nitrate removal rates, even for a similar type of reactor and carbon source (6.6 to $100 \mathrm{mg} \mathrm{NO}_{3}-\mathrm{N} \mathrm{L}^{-1} \mathrm{~h}^{-1}$ ) [44]. Directions for bioreactor improvement include studies of heterotrophic and autotrophic biofilter bacterial communities [15, 32], basic studies of nutrient balances in real systems, evaluation of adequate carbon sources and electron donors, and appropriate denitrifying bacterial population induction [44]. On the other hand, in experimental studies, the reproducibility necessary to 
understand biological phenomena and to enable model development requires the use of defined synthetic media and pure cultures [22]. However, the use of autochthonous species can provide data more related to the real situation under analysis.

A research program mainly focused on autochthonous denitrifying bacteria was undertaken in a commercial turbot production farm with an outdoor effluent treatment system where the implementation of biological denitrification to replace ozonation should be encouraged [6]. Because of the fact that there is not a recommended type of denitrification bioreactor for aquaculture systems and existing bioreactors still face design and operation problems, research was directed to elucidating systemspecific denitrifying bacteria behavior as a starting point. The present work describes the characterization of a marine denitrifying bacterium isolated from the fishfarm outdoor trickling filter and the quantification of aerobic and anoxic nitrogen removal. The evaluation of strain immobilization capacity to different support materials was also assessed. Such studies will help the development of models describing denitrification in real recirculation aquaculture systems and contribute to the knowledge on the role of heterotrophic bacteria in marine aquaculture nutrient removal systems.

\section{Methods}

\section{Commercial Turbot Farm Biofilter Colonization}

Studies. The work was carried out at a Portuguese commercial turbot production farm (60 tons per year) using tidal-dependent/recirculating seawater source, with an outdoor effluent treatment system composed of: mechanical screen filter $(60-\mu \mathrm{m}$ mesh size), homemade horizontal trickling filter (950 plastic boxes filled with plastic surpluses), and ozonation unit [6]. For colonization studies, four mesh boxes $(20 \times 20 \times 10 \mathrm{~cm}$, $4 \times 4 \mathrm{~mm}$ mesh size) filled with different sterile packing media (M1-blue plastic balls, F. Ribeiro Ld, $4 \mathrm{~cm} \varnothing$; M2-black bioballs, Biokaskade, $2.2 \mathrm{~cm} \varnothing$; M3expanded clay, Leca, $1 \mathrm{~cm} \varnothing$; M4-black plastic rings, Bioflow, $0.9 \mathrm{~cm} \varnothing$ ) were placed in the middle part of the biofilter and left undisturbed outdoors for 3 months during winter-spring time. As the biofilter was initially colonized by bacteria present in the seawater entering the fish farm, bacteria typical from this specific environment (autochthonous strains) should be recovered. Because submerged trickling filters tend to develop anoxic regions, the isolation of autochthon denitrifying strains was attempted.

Bacterial Strain Recovery, Enrichment, and Isolation. Culturable attached bacteria were recovered by scrapping with a sterile blade the material attached to the surface of a known weight of each matrix, which was then suspended in $10 \mathrm{~mL}$ of saline solution. The resulting suspensions were vortexed at maximum speed for $30 \mathrm{~s}$. Revivification was performed according to [29], after which $0.1 \mathrm{~mL}$ of appropriate dilutions $\left(10^{-1}\right.$ to $\left.10^{-7}\right)$ were spread-plated onto different solid media (in duplicate). Bacterial counting (colony forming units per

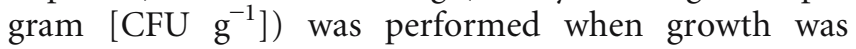
established, which changed with culture media and matrix used. Viable heterotrophic bacteria enumeration was obtained after 5-6 days incubation on Marine Agar (Difco 2216 ) at $25^{\circ} \mathrm{C}$. Isolation of marine nitrifying bacteria was attempted aerobically, at $25^{\circ} \mathrm{C}$, for $21-35$ days with nitrifying agar [24]. Isolation of nitrate-respiring bacteria (presumptive denitrifyers) was carried out using nitrate agar [37] with $28 \mathrm{~g} \mathrm{~L}^{-1} \mathrm{NaCl}$ and incubation for 11-14 days, at room temperature, in anaerobic jars [6]. Seven morphologically different colonies obtained in nitrate-agar were selected for purification by repeated streaking onto the same medium. The purified isolates were stored frozen in $20 \%$ glycerol $(\mathrm{v} / \mathrm{v})$ at $-80^{\circ} \mathrm{C}$ for further studies. Growth, measured as Optical Density (OD) readings at $600 \mathrm{~nm}$ on liquid medium (nitrate medium previously employed without agar added [37]), was used to select, from the different morphological types obtained, the denitrifying strains to be used for further studies.

Denitrifying Strains Phenotypic and Biochemical Characterization. Four isolates showing growth both in solid and liquid nitrate-supplemented medium (strains T1, T2, T3, and T4) were characterized through classical methods (Gram staining, colony and cell morphology, pigment, presence or absence of Cytochrome $c$ oxidase and catalase) and further identified using API $20 \mathrm{NE}$ system (Biomerieux), and the software program Apilab Plus (Biomerieux). Furthermore, Pseudomonas species identification was carried out with specific biochemical tests (arginine dihydrolase activity in MCA medium, gelatinase presence, fluorescent pigment production in King's B medium, growth in $\mathrm{PAB}$ [Pseudomonas Agar Base], Oxoid, at $4{ }^{\circ} \mathrm{C}$ and $41^{\circ} \mathrm{C}$ and hemolysis in sheepblood agar) [9]. Fatty Acid Methyl-Esther (FAME) analysis (performed by gas-chromatography at DSMZ, Braunschweig, Germany) was afterward used only in strain T2 characterization. This strain showed better growth in liquid medium and was chosen for subsequent studies. Presumptive $\mathrm{NO}_{3}^{-}$reduction and $\mathrm{N}_{2}$ formation were assessed for this strain as described in [9]. In all cases, appropriate positive and negative controls were used for comparison.

$16 S$ rRNA Gene Sequencing and Phylogenetic Analysis. The template DNA from strain T2 was obtained by boiling washed cell suspensions for $5 \mathrm{~min}$ in $50-\mu \mathrm{l}$ sterile distilled water and using $2 \mu \mathrm{L}$ of the 
supernatant. The $16 \mathrm{~S}$ rRNA gene was amplified by polymerase chain reaction (PCR) using the primer set f27-r1492 [26] under standard PCR conditions (30 cycles with annealing at $55^{\circ} \mathrm{C}$ ) with Taq DNA polymerase (MBI Fermentas, Lithuania). The amplified fragments were cloned into pGEM T-Easy vector (Promega) and sequenced by STAB Genomica, Lisbon, Portugal (Taq DyeDeoxy Terminator Cycle Sequencing and Model 373 A gel apparatus, Applied Biosystems) using vector primers and 16S-specific primer f357 [26]. BLAST searches were performed through the National Center for Biotechnological Information online service (http:// www.ncbi.nih.gov/BLAST). 16S rRNA sequences were obtained using the National Center for Biotechnology Information taxonomy databases (http://www.ncbi.nlm. nih.gov/Taxonnomy). The $16 \mathrm{~S}$ rRNA gene sequences were aligned using the BioEdit program (version 4.8.8) [16] and analyzed using programs DNAML, SEQBOOT (100 iterations), DNADIST (Kimura 2-parameter), NEIGHBOR and CONSENSE of the PHYLIP package [8]. An alignment of 18 sequences by 1345 nucleotides was done using Escherichia coli and Salmonella typhimurium as two-sequence outgroup.

Nucleotide Sequence Accession Number. The $16 \mathrm{~S}$ rRNA sequence of strain T2 has been submitted to the GenBank database under accession number AY874539.

Aerobic and Anoxic Growth Conditions and Carbon Sources Tested. Strain T2 was first grown aerobically at room temperature in peptone medium (PM, [37]) supplemented with $28 \mathrm{~g} \mathrm{~L}^{-1} \mathrm{NaCl}$ and $1 \mathrm{~g} \mathrm{~L}^{-1} \mathrm{KNO}_{3}$ in duplicate or triplicate batch cultures with shaking. The effect of salinity was tested in $\mathrm{PM}$ with or without $\mathrm{NaCl}$, at $25^{\circ} \mathrm{C}$. Utilization of different carbon sources for growth was tested in liquid cultures using minimal medium (MM, [4]) with $0.3 \mathrm{~g} \mathrm{~L}^{-1}$ of $\mathrm{KNO}_{3}$ [43]. A range of organic compounds typically used by Pseudomonas strains, selected according to Bergey's Manual of Systematic Bacteriology (mainly amino acids) [24], or commonly referred to in denitrification studies (methanol, sodium acetate, and glucose) were tested as substrates for strain T2. Yeast extract was used as a positive control (assuming 50\% carbon and $10.5 \%$ nitrogen composition) and $\mathrm{MM}$ without carbon as a negative control. Different $\mathrm{C} / \mathrm{N}$ ratios $(w / w)$ were used. Assays were done in duplicate or triplicate, at $22-25^{\circ} \mathrm{C}$ or $28-30^{\circ} \mathrm{C}$, with shaking. The possibility of anoxic growth was tested with PM or MM with yeast extract, glucose, sodium acetate, or methanol under the conditions described below for denitrification studies. PM without nitrate and MM without carbon were used as controls. Growth was monitored by measuring optical density of the cultures at $600 \mathrm{~nm}$ (UnicamHelios Gamma spectrophotometer). Conversion to dry cell weight was done using a calibration curve.
Aerobic Nitrate Removal Tests. The possibility of aerobic nitrate removal through the assimilatory or dissimilatory pathways was tested with strain $\mathrm{T} 2$ in $\mathrm{MM}$ supplemented with glucose $\left(3 \mathrm{~g} \mathrm{~L}^{-1}\right)$, in duplicate flasks, at $22^{\circ} \mathrm{C}$, with shaking. Different conditions were assayed: medium with one $\mathrm{N}$ source (either ammonia, using $0.5 \mathrm{~g} \mathrm{~L}^{-1}$ $\left(\mathrm{NH}_{4}\right)_{2} \mathrm{SO}_{4}$ or nitrate, using $\left.0.3 \mathrm{~g} \mathrm{~L}^{-1} \mathrm{KNO}_{3}\right)$ and medium with the two $\mathrm{N}$ sources. As a control, no $\mathrm{N}$ source was used. Bacteria were adapted to these conditions and samples were collected at $0,13,16,19$, and $22 \mathrm{~h}$ of incubation for dry weight evaluation and $\mathrm{N}$ analysis $\left(\mathrm{NH}_{4}-\mathrm{N}, \mathrm{NO}_{2}-\mathrm{N}\right.$, and $\mathrm{NO}_{3}-\mathrm{N}$ ).

Denitrification Studies. Anoxic conditions were obtained by filling serum bottles up to $80 \%$ capacity, flushing the headspace and culture medium with $\mathrm{N}_{2}$ for $>15 \mathrm{~min}$ and sealing them with rubber stoppers and aluminium seals. Two media with different organic loadings were used (PM and $\mathrm{MM}$ with $3 \mathrm{~g} \mathrm{~L}^{-1}$ yeast extract as electron donor and $1 \mathrm{~g} \mathrm{~L}^{-1}$ or $0.3 \mathrm{~g} \mathrm{~L}^{-1} \mathrm{KNO}_{3}$, respectively, as electron acceptor), being reduced after sterilization with a cistein solution $\left(10 \mathrm{~mL} \mathrm{~L}^{-1}\right)$ and monitored for redox potential changes during incubation with rezasurin at $10 \mathrm{~mL} \mathrm{~L}^{-1}$. Tests were done at $25^{\circ} \mathrm{C}$, in triplicate, with $\mathrm{NO}_{3}^{-}$as electron acceptor. Bacterial inocula were obtained from strain $\mathrm{T} 2$ cultures pregrown on these media. The effects of $\mathrm{C}$ sources and $\mathrm{C} / \mathrm{N}$ ratios on growth were evaluated under the conditions referred above. Although in denitrification studies it is common practice to add the carbon source stoichiometrically to reduce all available nitrate, in this work growth was studied using higher concentrations to avoid carbon limitation.

Immobilization of T2 Strain. Attachment of strain T2 to different packing media, granular activated carbon (GAC, Sigma-Aldrich, $0.2-0.3 \mathrm{~cm} \varnothing$ ), Filtralite $2 / 4$ (high-porosity expanded clay, $0.2-0.4 \mathrm{~cm} \varnothing$ ), black plastic rings (Bioflow, $0.9 \mathrm{~cm} \varnothing$ ), was evaluated. Tests were carried out by inoculating pregrown cultures of strain T2 in MM without any carbon source in closed flasks containing sterile support material, at room temperature, with gentle shaking. Appropriate positive and negative controls were used. The decrease in optical density and in CFU mL $\mathrm{m}^{-1}$ in the culture medium, and the increase in CFU g ${ }^{-1}$ of the extracted biofilm, were used as indicators of biomass loading onto each carrier.

Analytical Methods. Samples for chemical analysis were centrifuged at $5000 \mathrm{rpm}$ for $10 \mathrm{~min}$ and analyzed in triplicate for $\mathrm{NO}_{3}-\mathrm{N}$ using a modification of the spongy cadmium method [20]; and according to [2] for $\mathrm{NO}_{2}{ }^{-} \mathrm{N}$ and $\mathrm{NH}_{4}-\mathrm{N}$, after incubation at $37^{\circ} \mathrm{C}$ for $30 \mathrm{~min}$ [13]. The effect of salt interference in nitrate determination was minimized by the high dilutions employed. Salinity was measured using a refractometer (YSY Instruments) 
and $\mathrm{pH}$ with either a portable Oaklon meter or $\mathrm{pH}$ paper strips (Universalindikator Merck). All chemicals used were of analytical grade.

Mathematical Model and Statistical Analysis. Zeroorder nitrate consumption rate constants were calculated using nitrate concentration incubation data for each experimental condition and the linear regression model $[N]=\left[N_{0}\right]-r t$, where $N$ is the nitrate concentration $(\mathrm{mg}$ $\left.\mathrm{NO}_{3}-\mathrm{N} \mathrm{L}^{-1}\right), N_{0}$ is the initial nitrate concentration $(\mathrm{mg}$ $\mathrm{NO}_{3}-\mathrm{N} \mathrm{L}^{-1}$ ), $t$ is the incubation time (in hours), and $r$ is the zero-order reaction constant for nitrate consumption (mg NO${ }_{3}^{-} \mathrm{N} \mathrm{L}^{-1} \mathrm{~h}^{-1}$ ). Specific rates of nitrate reduction $(r / X)$ were obtained dividing the slope of the model by the biomass ( $X, \mathrm{mg} \mathrm{L}^{-1}$ dry cell mass) formed [11]. Results from batch tests were compared at the 95\% confidence level $(p<0.05)$ using Student's $t$-test or one-way analysis of variance (ANOVA) and a posteriori StudentNewman-Keuls test (Excel XP, Microsoft and Statistica 6.0 for Windows).

\section{Results}

\section{Enrichment and Strain Isolation and Characterization.}

Bacterial counts obtained after extracting the biofilm from each packing material was different in each culture medium used (Table 1). The biofilter studied was a nitrification unit and nitrifying bacteria would be important members of its bacterial community. In fact, CFU values observed per gram of matrix in nitrifying agar were higher than the values obtained using nitrate agar, but because of the long incubation time observed (up to 35 days, Table 1), and because denitrification was the main objective of this work, research proceeded only with $\mathrm{NO}_{3}$-agar-recovered bacteria. Through standard enrichment and purification techniques and preliminary growth tests, four bacterial isolates able to grow in liquid medium were obtained: strain T1 from blue plastic balls, strain T2 from Leca pieces, strains T3 and T4 from plastic rings. All of them formed small orange-yellow smooth colonies of Gram-negative rods, catalase and oxidase positive. Utilization of API 20 NE identification kits showed that all strains belonged to the Pseudomonas genus. Further tests for strain T2 pointed to a $57.2 \%$ probability of it being a $P$. fluorescens and a $40.1 \%$ probability toward $P$. aeruginosa. Results from $\mathrm{PAB}$ test were positive (green-yellow color) and negative for hemolysis and growth at $4{ }^{\circ} \mathrm{C}$ and $41^{\circ} \mathrm{C}$. Clear fluorescence was initially observed only with strain T1. Further tests with strain T2 showed fluorescence in King's B medium and positive results for gelatinase and arginine hydrolase tests. These results strongly indicated a fluorescent Pseudomonas. Because of better performance in preliminary growth tests in liquid medium and the evidence of $\mathrm{NO}_{3}^{-}$reduction with gas formation, strain $\mathrm{T} 2$ was chosen for subsequent studies. To confirm classical identification, FAME analysis was performed and showed that the main fatty acids extracted were 2- and 3-hydroxy acids with chain length of 10:0 and 12:0 carbon atoms combined with high amounts of unsaturated 16:1 and 18:1 $\omega-7$ fatty acids and a small amount of cyclopropane fatty acid 17:0. This profile, diagnostic of Pseudomonas species and related organisms, confirmed the results obtained with the API tests.

Molecular Classification of Strain T2. A nearcomplete 16S rRNA gene (1457 bp) was amplified from the genomic DNA extracted from strain T2, cloned, and sequenced. BLAST searches showed that strain rRNA sequence was very similar to those of fluorescent Pseudomonas strains. Subsequent phylogenetic analysis (Fig. 1) confirmed that strain T2 belongs to the fluorescent $P$ seudomonas group, presenting 99\% similarity with P. gessardii strain CIP 105469 (AF074384), P. libanensis strain CIP 105460 (AF057645), P. reactans strain LMG 5329 (AF255337), P. fluorescens strain PC24 (AF228367), and $98 \%$ similarity with $P$. synxantha strain G (AF267911).

Effect of Salinity and Temperature on Aerobic Growth of Strain T2. Aerobic incubation of strain T2 in PM at $25^{\circ} \mathrm{C}$, with or without $\mathrm{NaCl}$ resulted in similar growth curves (Fig. 2) with nonsignificant differences in final biomass ( $t=-0.067, p=0.948, n=11)$. The effect of temperature was assayed using $\mathrm{MM}$ with either glucose or L-glutamic acid, at $22^{\circ} \mathrm{C}$ or $28^{\circ} \mathrm{C}$. Irrespective of the carbon source used in the medium, growth was impaired

Table 1. Bacterial counts (mean \pm standard deviation) from outdoor fish farm biological filter with different packing media

\begin{tabular}{|c|c|c|c|c|c|c|}
\hline \multirow[b]{2}{*}{ Packing } & \multicolumn{2}{|l|}{ Marine agar } & \multicolumn{2}{|l|}{$\mathrm{NO}_{3}$ agar } & \multicolumn{2}{|c|}{ Nitrifying agar } \\
\hline & Time (days) & $C F U\left(\times 10^{6} g^{-1}\right)$ & Time (days) & $C F U\left(\times 10^{3} g^{-1}\right)$ & Time (days) & $C F U\left(\times 10^{4} g^{-1}\right)$ \\
\hline M1 & 5 & $1.1 \pm 0.2$ & 14 & $7.5 \pm 0.5$ & 35 & - \\
\hline M2 & 5 & $2.6 \pm 0.2$ & - & - & 23 & $1.8 \pm 0.2$ \\
\hline M3 & 6 & $1.3 \pm 0.1$ & 14 & $0.3 \pm 0.1$ & 21 & $6.2 \pm 0.7$ \\
\hline M4 & 6 & $0.9 \pm 0.1$ & 11 & $4.5 \pm 0.2$ & 21 & $6.3 \pm 0.1$ \\
\hline
\end{tabular}

M1: Blue plastic balls; M2: black bioballs; M3: Leca; M4: plastic rings. Time: incubation time needed to observe growth; $-=$ counting not possible or sample contamination. 


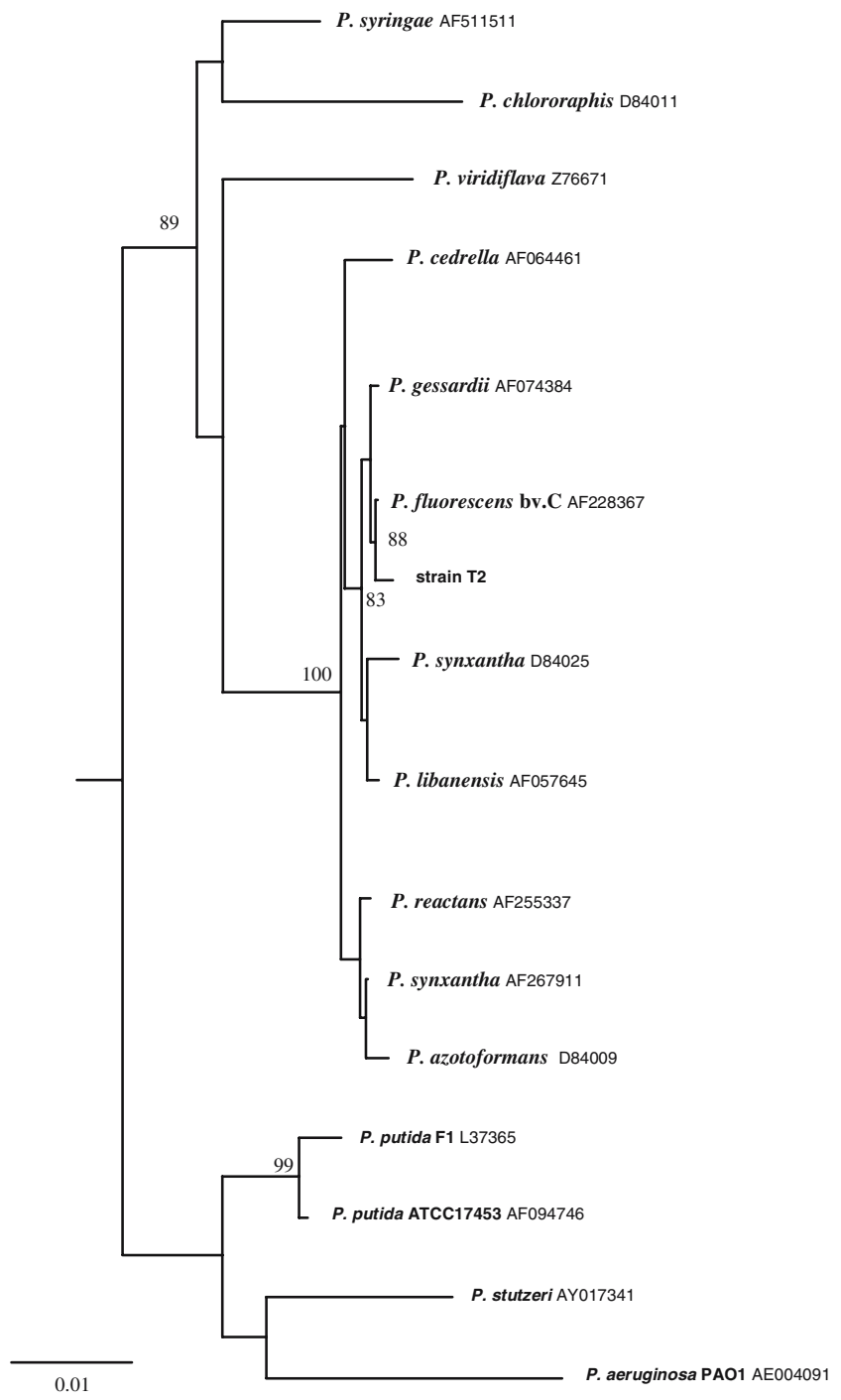

Figure 1. Neighbor-joining tree of $16 \mathrm{~S}$ rRNA analysis. Numbers at branch nodes indicate the bootstrap values over 100 replicates. Only values $>70$ are shown.

at high temperature (Fig. 3). On the other hand, at $22^{\circ} \mathrm{C}$, although maximum growth rates were similar between carbon sources $\left(\mu=0.11-0.10 \mathrm{~h}^{-1}\right)$, maximum biomass production in $30 \mathrm{~h}$ was $32 \%$ higher using the amino acid as a carbon source.

Carbon Source Utilization and C/N Ratios. One of the main factors affecting bacterial growth is the carbon source available. The ability of strain T2 to use different carbon sources was evaluated (Tables 2 and 3). Growth was evident both under oxic or anoxic conditions and at various $\mathrm{C} / \mathrm{N}$ ratios. Best performance in terms of growth rate under aerobiosis at $22^{\circ} \mathrm{C}$ was registered using either undefined, semi-defined, or defined media with similar amounts of glucose, $\mathrm{L}$-glutamic acid, or L-proline (3-4 $\mathrm{g} \mathrm{L}^{-1}$ used; $0.10-0.14 \mu_{\max } \mathrm{h}^{-1}$ obtained). In terms of biomass formed, results favor the use of L-glutamic acid followed by L-proline and glucose for $\mathrm{MM}$ supplementation $(F=4.45, \quad p=0.04, n=15)$. Although growth was observed with acetate at a concentration of $2 \mathrm{~g} \mathrm{~L}^{-1}$, this strain seemed not to tolerate higher concentrations of this C-source, as growth stopped for the highest concentration tested (Table 2). Regarding $\mathrm{C} / \mathrm{N}$ ratios, better growth was usually obtained when this ratio approached the theoretical biomass composition ratio of 4, with the exception of glucose medium. Under anoxia, with the exception of PM, growth rates were much lower, about one-third of the values obtained under oxic conditions, and were very similar among the media assayed (Table 3). Best rates with MM were obtained using the lowest amount of carbon sources tested $\left(0.2-0.3 \mathrm{~g} \mathrm{~L}^{-1}\right)$, representing rather low $\mathrm{C} / \mathrm{NH}_{4}-\mathrm{N}$ ratios, but $\mathrm{C} / \mathrm{NO}_{3}-\mathrm{N}$ ratios closer to the stoichiometric values for denitrification. ANOVA test showed no significant differences in amounts of biomass formed $(F=1.73, p=0.16, n=35)$. For longer-term studies (up to $86 \mathrm{~h}$ of incubation), the use of MM with glucose, followed by sodium acetate, seemed to enhance bacterial growth. Methanol did not favor growth under these conditions, and growth impairment was observed after $23 \mathrm{~h}$ of incubation. In any situation, controls without carbon source showed no growth.

Aerobic Nitrate Utilization. The possibility of nitrate utilization as $\mathrm{N}$ source for assimilative metabolism by strain T2 was tested and results are presented in Table 4. Effectively, this bacterium can grow using only $\mathrm{NO}_{3}-\mathrm{N}$, although at a rate slightly lower comparedtotheuseofammonium $\left(\mu=0.076 \mathrm{~h}^{-1}\right.$ vs $\left.0.09 \mathrm{~h}^{-1}\right)$. Nevertheless, the presence of both $\mathrm{N}$ sources in the medium did not seem to affect growth significantly $\left(\mu=0.097 \mathrm{~h}^{-1}\right)$. Twenty-two-hour biomass production was similar using ammonium or both $\mathrm{N}$ sources, $179 \mathrm{mg} \mathrm{L}^{-1}$, and decreased to $104 \mathrm{mg} \mathrm{L}^{-1}$ using only $\mathrm{NO}_{3}-\mathrm{N}$ at either $0.3 \mathrm{~g} \mathrm{~L}^{-1} \mathrm{KNO}_{3}$ or $0.76 \mathrm{~g} \mathrm{~L}^{-1} \mathrm{KNO}_{3}$ (the latter concentration was tested to have a $\mathrm{N}$ level in nitrate

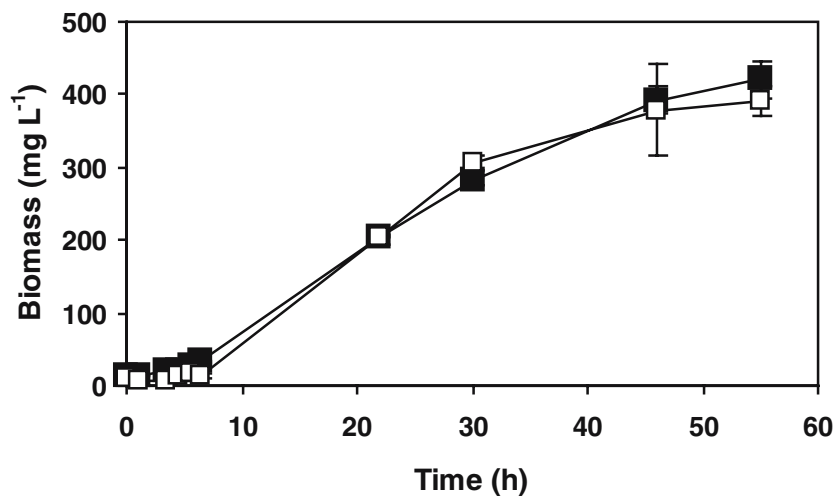

Figure 2. Salinity effect on aerobic growth of strain T2 in peptone medium at $25^{\circ} \mathrm{C}$; ( $) 0 \% \mathrm{NaCl},(\square) 2.8 \% \mathrm{NaCl}$. Data represent mean and standard deviation of duplicate samples. 

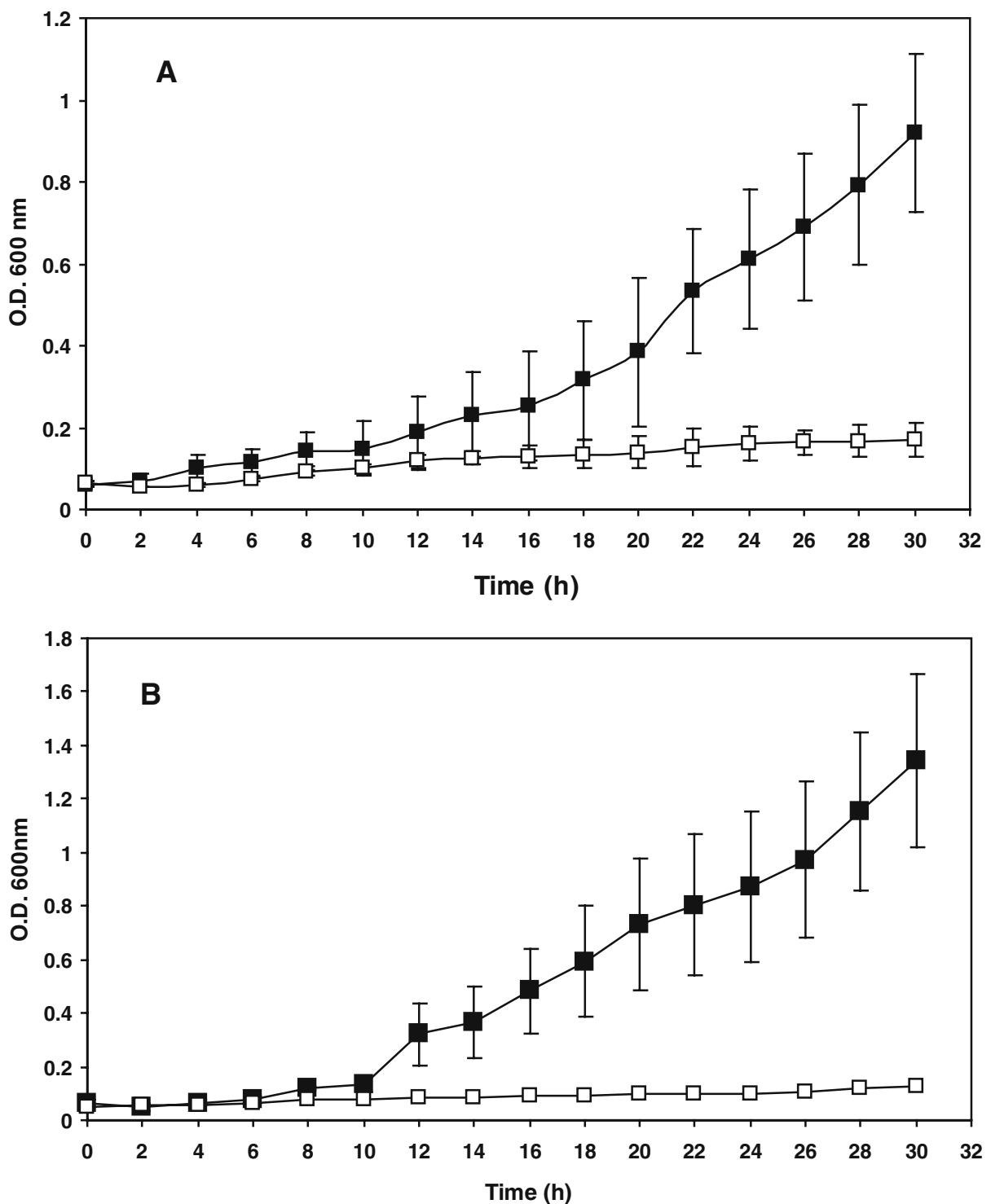

Figure 3. Effect of temperature on aerobic growth of strain T2 in minimal medium supplemented with glucose (A) or L-glutamic acid (B) as carbon sources; $(\square) 22^{\circ} \mathrm{C},(\square) 28^{\circ} \mathrm{C}$. Data points are averages of triplicate measurements \pm standard deviation.

medium equivalent to the concentration in ammonium medium). Quantification of $\mathrm{N}$ removal rates showed that nitrate could be aerobically assimilated with efficiency up to $65 \%$ in nitrate medium (Table 4). Calculated nitrate aerobic specific assimilation rates varied from 116.2 to $81.9 \mathrm{mg} \mathrm{NO}-\mathrm{N} \mathrm{g} \mathrm{dw}{ }^{-1} \mathrm{~h}^{-1}$ using only $\mathrm{NO}_{3}$ or both $\mathrm{N}$ sources, respectively. Ammonia was assimilated up to $29 \%$ using both $\mathrm{N}$ sources. No growth was observed in the controls without $\mathrm{N}$ source. Although oxygen levels were not measured during all of the aerobic experiments, the presence of sufficient oxygen for growth could be assumed by the behavior of the ammonia-medium cultures, where there was no nitrate to be used as electron acceptor in case of oxygen depletion. Under aerobiosis, a transient nitrite formation was found when using $\mathrm{NO}_{3}$ containing media, with a maximum of $0.17 \mathrm{mg} \mathrm{L}^{-1}$ at 16 $\mathrm{h}$ of incubation in the ammonia plus nitrate medium. This nitrite concentration represented $21.5 \%$ of the maximum nitrite obtained under anoxia in MM. No gas formation was observed. With nitrate as the sole $\mathrm{N}$ source, nitrite formation was lower $\left(0.1 \mathrm{mg} \mathrm{L}^{-1}\right)$; in both cases, no detectable $\mathrm{NO}_{2}$ levels were found at 19-22 $\mathrm{h}$ of incubation. These findings suggest a limited capacity of aerobic dissimilatory metabolism.

Denitrification Batch Tests. Strain T2 denitrification ability was tested in batch cultures using either a high organic loading medium (PM) or a low organic medium (MM). Nitrate and nitrite reduction and cell growth occurred under both situations. Growth stopped after the exhaustion of the electron acceptors, a phenomenon most evident in PM, where carbon should 
Table 2. Strain T2 aerobic growth in minimal medium supplemented with different carbon sources and in peptone medium

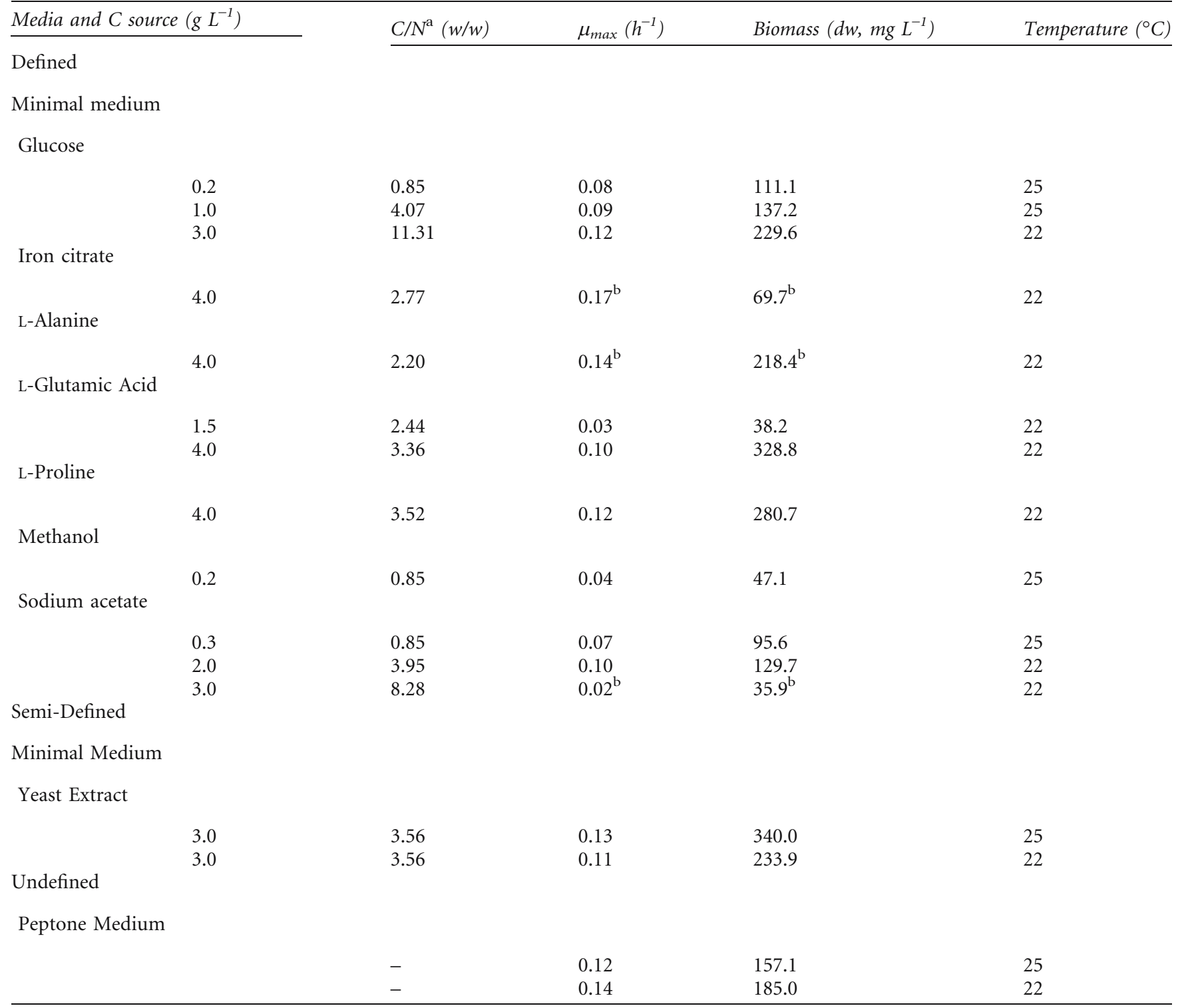

Incubation time $(t): 22-24 \mathrm{~h}$; Control: no $\mathrm{C}$ source

${ }^{a} \mathrm{~N}$ source for synthesis in minimal medium: $\left(\mathrm{NH}_{4}\right)_{2} \mathrm{SO}_{4}+$ organic $\mathrm{N}$ (amino acids and yeast extract)

${ }^{\mathrm{b}}$ Growth stopped after $10-12 \mathrm{~h}$

not be a limiting factor. Intermediate nitrite production was clearly observed with PM resulting in a transient nitrite accumulation of up to $110-130 \mathrm{mg} \mathrm{L} \mathrm{m}^{-1}$. In MM transient nitrite accumulation was negligible $\left(0.81 \mathrm{mg} \mathrm{L}^{-1}\right)$. Nitrite was totally reduced after $40 \mathrm{~h}$ in $\mathrm{PM}$ and after $25 \mathrm{~h}$ for cultures in MM (Fig. 4). Complete nitrate removal $(E=100 \%)$ was observed in $44 \mathrm{~h}$ using PM and in $25 \mathrm{~h}$ for MM. Specific removal rates (Table 5) varied from 30.9 (PM) to $53.5 \mathrm{mg} \mathrm{NO}_{3}-\mathrm{N} \mathrm{g} \mathrm{dw}^{-1} \mathrm{~h}^{-1}$ (MM).

Strain T2 Immobilization. The capacity of strain T2 to adsorb to different packing media was preliminarily assessed using GAC, Filtralite and Bioflow rings in batch tests at $25^{\circ} \mathrm{C}$. Results indicate adhesion to all substrates tested after $72 \mathrm{~h}$ exposure, especially to GAC, although matrix ranking changed with the methodology used for quantifying adhesion. In fact, using optical density higher adhesion with time was observed with GAC (37.7\% OD reduction), followed by Filtralite (14.2\%) and Bioflow rings (12.0\%); using $\mathrm{CFU} \mathrm{mL}^{-1}$ evaluation in the culture supernatant, final values were similar among substrata $\left(2.4,2.53,2.21 \times 10^{8} \mathrm{CFU} \mathrm{mL}^{-1}\right.$, respectively, from an initial value of $3.18 \times 10^{8} \mathrm{CFU} \mathrm{mL}^{-1}$ ), but ranking changed again when CFU per gram of matrix were calculated (9.58, $6.48,3.17 \times 10^{8} \mathrm{CFU} \mathrm{g}^{-1}$, respectively). In all cases, changes in the controls were negligible. 
Table 3. Anoxic growth of strain T2 in minimal medium supplemented with different carbon sources or in peptone medium

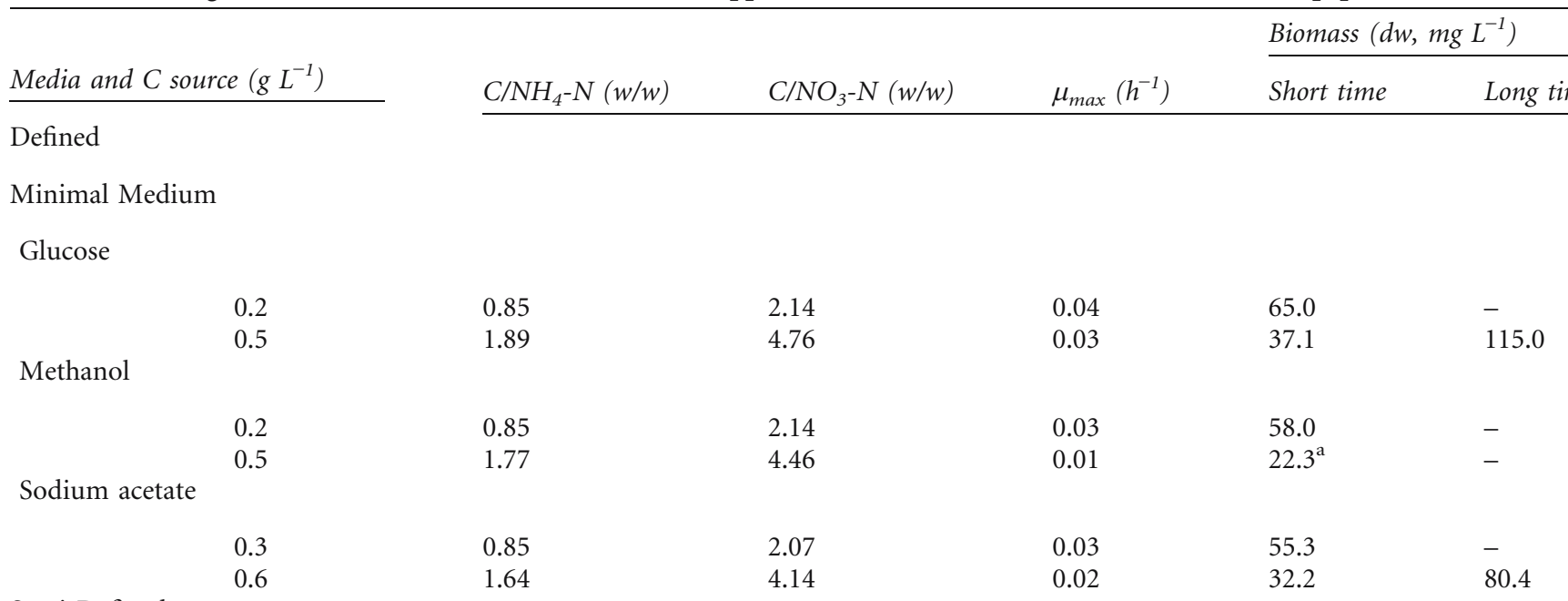

Semi-Defined

Minimal Medium

Yeast Extract

$3.0 \quad 3.56^{\mathrm{b}} \quad 35.71$

78.2

Undefined

Peptone Medium

$\begin{array}{llll}- & 0.09 & 117.0 & 202.1\end{array}$

Incubation time $(t)$ : Short $(22-24 \mathrm{~h})$ and long $(86 \mathrm{~h})$; temperature: $25^{\circ} \mathrm{C}$; controls: no C source and no $\mathrm{NO}_{3}-\mathrm{N}$.

${ }^{\mathrm{a}}$ Growth stopped after $23 \mathrm{~h}$ of incubation.

${ }^{\mathrm{b}} \mathrm{N}$ source for synthesis: $\left(\mathrm{NH}_{4}\right)_{2} \mathrm{SO}_{4}+$ organic $\mathrm{N}$

\section{Discussion}

Studies on the composition and ecology of marine biofilter bacterial communities are of outmost importance for nitrogen removal improvement. Most typically, data on this matter are obtained from experimental labscale reactors, whereas research in large-scale commercial systems would provide more realistic data. The results obtained in this study of outdoor biofilter colonization in situ at a turbot farm, compared to the indoor experimental systems reported in the literature, showed a maximum bacterial loading of $2.6 \times 10^{6} \mathrm{CFU} \mathrm{g}^{-1}$, which was lower than $2.1 \times 10^{7} \mathrm{CFU} \mathrm{g}^{-1}$ found in a sea bass recirculation system [29], but higher or similar to the values reported for pilot scale seawater biofilters, $5.0 \times 10^{4}$ to $4.4 \times 10^{6} \mathrm{CFU} \mathrm{g}^{-1}$, working with $\mathrm{C} / \mathrm{N}$ ratios from 0 to 2
[32]. Differences observed can be attributed not only to different system configuration and operation, but also to the use of different packing media (Table 1). Under the conditions assayed (outdoors, $12-14^{\circ} \mathrm{C}, 28-30 \%$ salinity), a considerable number of nitrifying bacteria of different morphological types were found, especially in carriers with lower heterotrophic bacterial load, in line with results from nitrifying biofilter communities [32, 40]. Further characterization of such morphotypes would be important in the future because almost no information exists on the characterization of aquaculture nitrifying biofilter consortia [40]. Nitrate respiring bacteria were found in lower numbers and morphotypes and represented about half of the total culturable heterotrophic bacterial CFU per gram of carrier. The existence of heterotrophic facultative aerobic bacteria in aquaculture

Table 4. Aerobic ammonium and nitrate utilization as $\mathrm{N}$ source for assimilative metabolism by strain $\mathrm{T} 2$ in minimal medium supplemented with $3 \mathrm{~g} \mathrm{~L}^{-1}$ glucose, at $22^{\circ} \mathrm{C}$

\begin{tabular}{lllll}
\hline $\mathrm{N}$ sources & $\mu_{\max }\left(h^{-1}\right)$ & Biomass $\left(d w, m g L^{-1}\right)$ & $\mathrm{N}$ removal efficiency $(E, \%)$ & $\mathrm{NO}_{3}-\mathrm{N}$ removal rate $\left(m g ~_{\left.\mathrm{NO}_{3}-\mathrm{NL}^{-1} h^{-1}\right)}\right.$ \\
\hline $\mathrm{NH}_{4}-\mathrm{N}+\mathrm{NO}_{3}-\mathrm{N}$ & 0.090 & 179.0 & $\mathrm{NH}_{4}-\mathrm{N}=29.11 ; \mathrm{NO}_{3}-\mathrm{N}=59.74$ & $-3.414, r^{2}=0.96$ \\
$\mathrm{NH}_{4}-\mathrm{N}$ & 0.097 & 179.0 & 23.81 & - \\
$\mathrm{NO}_{3}-\mathrm{N}$ & 0.076 & 104.0 & 65.41 & $-3.086, r^{2}=0.91$ \\
\hline
\end{tabular}

Incubation time $(t): 22 \mathrm{~h}$; control: no $\mathrm{N}$ source. 

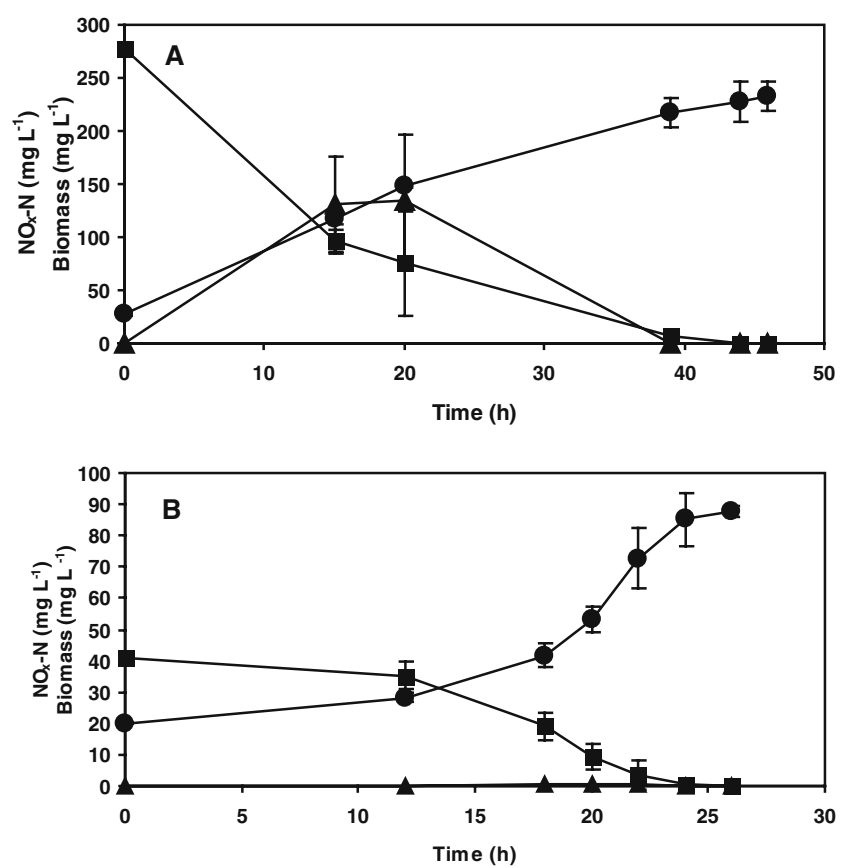

Figure 4. Strain $\mathrm{T} 2$ anoxic growth and denitrification behavior using either peptone medium (A) or minimal medium (B) at

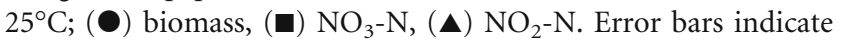
standard deviation.

biofilters that are typically operated aerobically could be explained by the presence of hypoxic microsites [44]. These bacteria can remove nitrate nitrogen via a dissimilatory process, conducting to $\mathrm{N}_{2}$ via $\mathrm{NO}_{2}^{-}$(in the case of true denitrifying organisms under optimal conditions) or to a variety of intermediates (nitrate-respiring bacteria). Presumptive denitrifying isolates obtained and characterized in this study were classified as Pseudomonas, a genus commonly found in wastewater treatment systems [31], detected especially when plating techniques are employed. A high heterogeneity and diversity within Pseudomonas genus is well-known and a number of Pseudomonas strains exhibit denitrification capacity, even in marine aquaculture systems [24]. However, strain classification within this genus is difficult, requiring multiple physiological tests, advanced phenotypic and molecular methods [41]. In the present study, a thorough classification effort was applied to the fastest growing strain, strain T2, initially to differentiate between the $P$. fluorescens (nonpathogenic) and $P$. aeruginosa (potentially pathogenic) API $20 \mathrm{NE}$ alternative results. Afterward, strain assignment to the P. fluorescens lineage could only be established by $16 \mathrm{~S}$ rRNA gene sequence analysis. This represents an important starting step because in many cases, authors define poorly the Pseudomonas strains used in their studies [41], which may have implications in their subsequent experimental utilization. Phylogenetic analysis showed a close proximity (98-99\% similarity) of strain T2 to some members of this cluster inhabiting environments very different from a marine biofilter, such as $P$. gessardii str. strain CIP 105469 (isolated from French natural mineral waters [45]), $P$. libanensis str. strain CIP 105460 (isolated from spring waters in Lebanon [7]), $P$. synxantha strain $\mathrm{G}$ (AF057645) (isolated from Scotch pine buds in Finland [35]), P. reactans LMG 5329 (AF255337) (inhabiting cultivated mushrooms hyphosphere [33]) and $P$. fluorescens strain PC24 (AF228367) (isolated from phenolic compounds in polluted river water [18]). As for nitrogen removal capacity, Baïda et al. [3] refer that denitrification (as reduction of $\mathrm{NO}_{3}^{-}$to $\mathrm{NO}_{2}^{-}$) was not observed in $P$. libanensis, but was observed in 11-89\% of $P$. gessardii strains studied and in biovars II, III, and IV of $P$. fluorescens. These findings confirm the need for further research in biofilter community analysis in the aquaculture settings, to understand the conditions determining the presence and function of specific bacteria in these systems, as is the case of strain $\mathrm{T} 2$.

Physiological and biochemical studies carried out aimed at describing the isolated strain behavior under specific environmental conditions relevant for its future use in bioreactor research. Because in the fish farming industry different fish species with varying salinity optima are used [19], both freshwater and full seawater conditions were tested in this study in aerobic conditions. Strain T2 showed no salinity requirement for growth, which matches the findings for all strains of $P$. brenneri, another Pseudomonad isolated from French natural mineral waters [3] and for a Pseudomonas strain isolated from the Ariake Sea [21]. Regarding temperature preferences, it is known that Pseudomonas fluorescens are mesophilic organisms, with temperature optima between $25^{\circ} \mathrm{C}$ and $30^{\circ} \mathrm{C}$ [36]. Nevertheless, our strain showed marked growth difficulties when temperatures approached $28^{\circ} \mathrm{C}$, irrespective of the carbon source used. This behavior differs from some published work in aquaculture with other denitrifiers such as $P$. stutzeri, with best denitrifying performances and optimal bioreactor operation at $30^{\circ} \mathrm{C}$ [43]. On the other hand, the

Table 5. Anoxic nitrogen removal by strain $\mathrm{T} 2$ in peptone medium (PM) and minimal medium (MM) at $25^{\circ} \mathrm{C}$, with ammonium as nitrogen source

\begin{tabular}{|c|c|c|c|c|}
\hline $\begin{array}{l}\text { Culture medium } \\
\text { and } C \text { source }\end{array}$ & $\mu_{\max }\left(h^{-1}\right)$ & $\begin{array}{l}N \text { removal } \\
\text { efficiency }(E, \%)\end{array}$ & $\begin{array}{l}\mathrm{NO}_{3}-\mathrm{N} \text { removal } \\
\quad \text { rate }\left(m g \mathrm{NO}_{3}-\mathrm{NL}^{-1} h^{-1}\right)\end{array}$ & $\begin{array}{l}\mathrm{NO}_{3}-\mathrm{N} \text { specific removal } \\
\quad \text { rate }\left(\mathrm{mg} \mathrm{NO} \mathrm{NO}_{3}-\mathrm{Ngdw}^{-1} h^{-1}\right)\end{array}$ \\
\hline PM, undefined & 0.09 & $100(44 \mathrm{~h})$ & $-3.427, r^{2}=0.98$ & 30.99 \\
\hline MM, yeast extract & 0.04 & $100(25 \mathrm{~h})$ & $-3.043, r^{2}=0.99$ & 53.50 \\
\hline
\end{tabular}


preference for lower temperatures may be an interesting trait in the development of bacterial treatment systems for cultivation of colder-water fish species.

The remarkable metabolic versatility of Pseudomonas strains, which is one of the possible causes for the ubiquity of this genus, was confirmed in our carbon utilization profiles. Of the various substrates tested, higher growth rates were obtained with readily oxidizable organic molecules (sugars and amino acids), which are known to be utilized with efficiencies reaching $80-90 \%$ [12]. Regarding the stoichiometric balance of main nutrients for cell synthesis $(\mathrm{C} / \mathrm{N}$ ratio), substrate ratios found in previous studies to favor nutrient consumption for incorporation into cell mass have been reported as equal or higher than cell ratios [12]. In our experiments, $\mathrm{C} / \mathrm{N}$ ratios either approached bacterial cell values $(\mathrm{C} / \mathrm{N}=4-5$, yielding the best growth results under aerobiosis, globally), or varied from severe $\mathrm{C}$ limitation $(\mathrm{C} / \mathrm{N}=0.85)$ to $\mathrm{N}$ limitation $(\mathrm{C} / \mathrm{N}=8.28-11.31$, Table 2$)$, showing less optimal growth. Nevertheless, because of some small differences in ambient temperature registered during some of these experiments, possible temperature effects on the results obtained should be further investigated. When growth tests were performed under anoxic conditions using nitrate as electron acceptor, strain T2 showed to be a facultative aerobe, growing either oxically or anoxically. The significantly lower growth rates obtained without oxygen were expected and agree with the results obtained with $P$. denitrificans in batch tests with L-glutamic acid as $\mathrm{C}$ and $\mathrm{N}$ source [23]. Nevertheless, differences in strains and culture conditions preclude direct comparison of observed growth rates. The fact that methanol, an external carbon source commonly used in wastewater denitrification, did not favor T2 aerobic growth has been also referred by other authors working with pure Pseudomonas cultures $[21,27,38]$. Possible explanations for this behavior are either a strain requirement for yeast extract for methanol utilization [38] or an intrinsic inability to utilize this substrate: in fact, when natural consortia are used as bioreactor inocula, methanol usually selects, after a prolonged period of adaptation, for bacteria capable of rapidly assimilating C1-sources, like Hyphomicrobium and not for high numbers of Pseudomonas [17, 27, 28]. On the other hand, acetate was more efficiently used aerobically (as observed with glucose), but only when using $0.3-2.0 \mathrm{~g} \mathrm{~L}^{-1}$ and not higher concentrations. This fact might be explained by medium $\mathrm{pH}$ changes, despite culture medium standard buffering conditions, and higher ATP hydrolysis for excess cellular proton exportation [39] at higher acetate concentrations. Anoxically, the type of carbon source used seemed to affect final biomass yields only after extended cultivation periods. Higher yield values were obtained in MM with glucose or in peptone medium and lower with methanol, in agreement with findings of other authors [27]. Bacteria have transport systems enabling efficient uptake of either inorganic (as $\mathrm{NH}_{4}, \mathrm{NO}_{3}^{-}$) or organic (as amino acids) nitrogen [12]. Nevertheless, regarding nitrate removal studies, the ability of bacteria to use $\mathrm{NO}_{3}^{-}$aerobically for growth and/or respiration is seldom assessed. Our results showed an aerobic assimilatory $\mathrm{NO}_{3}^{-}$removal of $65 \%$ and limited aerobic denitrification. This ability can have a significant practical use, as nitrate loads can be initially reduced aerobically, when biomass is forming in an aerated tank, and then, the remaining load can be anoxically converted to $\mathrm{N}_{2}$ in a denitrification tank using smaller inputs of external carbon source. Also, some nitrate might be reduced by aerobic denitrification simultaneously to nitrification in nitrification basins. This opens different operation perspectives for nitrogen removal processes in recirculation seawater treatment systems. Anoxically, strain T2 showed typical denitrifying behavior, sequentially converting nitrate to nitrite and to gaseous products. The slower nitrate reduction rate observed in $\mathrm{PM}$ when nitrite concentration was high (Fig. $4 \mathrm{~A}, 130 \mathrm{mg} \mathrm{L}^{-1}$ ) can be attributed to the inhibitory effect of $\mathrm{HNO}_{2}$ on bacterial denitrification at this nitrite concentration at neutral $\mathrm{pH}$ [11]. Nitrate removal rates evaluated anoxically in batch conditions agree well with the data from a seawater public aquarium ([25], $r={ }^{-} 3.38 \mathrm{mg} \mathrm{NO} \mathrm{L}^{-1} \mathrm{~h}^{-1}$ in optimal conditions) and specific rates are well within the values referred for intensive aquaculture effluents and a consortium dominated by Pseudomonas sp. (76.2-92.4 $\mathrm{mg} \mathrm{NO}_{3} \mathrm{~g}$ biomass $^{-1} \mathrm{~h}^{-1}$ [1]), or for a consortium with Pseudomonas sp. and some Hyphomicrobium sp. (30-45 $\mathrm{mg} \mathrm{NO}_{3}$ gTSS $^{-1} \mathrm{~h}^{-1}$ with methanol [27]), or for high salinity effluents (19-50 mg NO 3 gMLSS $^{-1} \mathrm{~h}^{-1}$ [10]).

In biological wastewater treatment, fixed biomass systems have been widely employed [31]. Adhesion to surfaces and biofilm formation are complex phenomena favored by factors like matrix porosity and surface characteristics. GAC combines high porosity with adsorption of organics and ammonia [30] and thus represent an excellent substrate for attachment and growth. Nevertheless, because of economical constraints, plastic rings or expanded clay represent more viable options for further studies to be conducted under dynamic conditions. Other aspects to be investigated in further research with strain T2 include characterization and quantification of denitrification gaseous products, besides the evaluation of other metabolic traits with impact on bioreactor improvement, like the capacity of simultaneous nitrogen and phosphorus removal.

Studies such as the one presented in this article can help the development of models describing denitrification in real recirculation aquaculture systems and thus contribute to bioreactor improvement. This work represents a contribution to the knowledge on heterotrophic bacteria in marine aquaculture nutrient removal systems. 


\section{Acknowledgments}

The authors acknowledge the fish farm owner for permission, the farm biologist for assistance and $\mathrm{N}$. Gomes for kindly supplying the black plastic bioballs tested. We wish to also acknowledge the support provided by P. Moradas-Ferreira, IBMC.

\section{References}

1. Aboutboul, Y, Arviv, R, van Rijn, J (1995) Anaerobic treatment of intensive fish culture effluents: volatile fatty acid mediated denitrification. Aquaculture 133: 21-32

2. Aminot, A, Chaussepied, M (1983) Manuel des Analyses Chimiques en Milieu Marin. CNEXO, Brest, $439 \mathrm{p}$

3. Baïda, N, Yazourh, A, Singer, E, Izard, D (2001) Pseudomonas brenneri sp. nov., a new species isolated from natural mineral waters. Res Microbiol 152: 493-502

4. Bastos, F, Bessa, J, Pacheco, CC, De Marco, P, Castro, PML (2002) Enrichment of microbial cultures able to degrade 1,3-dichloro-2propanol: a comparison between batch and continuous methods. Biodegradation 13: 211-220

5. Blancheton, JP (2000) Developments in recirculation systems for Mediterranean fish species. Aquac Eng 22: 17-31

6. Borges, M-T, Morais, A, Castro, PML (2003) Performance of outdoor treatment systems for recirculation in an intensive turbot (Scophthalmus maximus) farm. Aquaculture International 11: 557-570

7. Dabboussi, F, Hamze, H, Elomari, M, Verhille, S, Baïda, N, Izard, D, Leclerc, H (1999) Pseudomonas libanensis sp. nov., a new species isolated from Lebanese spring waters. Int J Syst Bacteriol 49: 1091-1101

8. Felsenstein, J (1995) Phylogeny inference package, version 3.57c. University of Washington, Seattle

9. Gerhardt, P, Murray, RGE, Wood, WA, Krieg, NR (1994) Methods for General and Molecular Bacteriology. American Society for Microbiology, Washington, DC, $791 \mathrm{p}$

10. Glass, C, Silverstein, J (1999) Denitrification of high-nitrate, highsalinity wastewater. Water Res 33: 223-229

11. Glass, C, Silverstein, J, Oh, J (1997) Inhibition of denitrification in activated sludge by nitrite. Water Environ Res 69: 1086-1093

12. Goldman, JC, Caron, DA, Dennett, MR (1987) Regulation of gross growth efficiency and ammonium regeneration in bacteria by substrate C:N ratio. Limnol Oceanogr 32: 1239-1252

13. Grassoff, K, Ehrhardt, M, Kremling, K (Eds) (1983) Methods of Seawater Analysis. 2nd Ed. Verlag-Chemie, Weinheim, $419 \mathrm{p}$

14. Grguric, G, Wetmore, SS, Fournier, RW (2000) Biological denitrification in a closed seawater system. Chemosphere 40: 549-555

15. Gutierrez-Wing, MT, Malone, R (2006) Biological filters in aquaculture: Trends and research directions for freshwater and marine applications. Aquac Eng 34: 163-171

16. Hall, TA (1999) BioEdit: a user-friendly biological sequence alignment editor and analysis program for Windows 95/98/NT. Nucleic Acids Symp Ser 41: 95-98

17. Hallin, S, Pell, M (1998) Metabolic properties of denitrifying bacteria adapting to methanol and ethanol in activated sludge. Water Res 32: 13-18

18. Heinaru, E, Truu, J, Stottmeister, U, Heinaru, A (2000) Three types of phenol and p-cresol catabolism in phenol- and p-cresoldegrading bacteria isolated from river water continuously polluted with phenolic compounds FEMS. Microbiol Ecol 31: 195-205

19. Huguenin, JE, Colt, J (1989) Design and operating guide for aquaculture seawater systems. Elsevier Interscience, Amsterdam, The Netherlands, $264 \mathrm{p}$

20. Jones, MN (1984) Nitrate reduction by shaking with cadmium: alternative to cadmium columns. Water Res 18: 643-646
21. Kariminiaae-Hamedaani, H-R, Kanda, K, Kato, F (2004) Denitrification activity of the bacterium Pseudomonas sp. ASM-2-3 isolated from the Ariake Sea tideland. J Biosci Bioeng 97: 39-44

22. Kornaros, M, Zafiri, C, Lyberatos, G (1996) Kinetics of denitrification by Pseudomonas denitrificans under growth conditions limited by carbon and/or nitrate or nitrite. Water Environ Res 68: 934-945

23. Kornaros, M, Lyberatos, G (1998) Kinetic modelling of Pseudomonas denitrificans growth and denitrification under aerobic, anoxic and transient operating conditions. Water Res 32: 1912-1922

24. Krieg, N, Holt, JG (Eds) (1984) Bergey's Manual of Systematic Bacteriology, vol. I. Williams and Wilkins, $964 \mathrm{p}$

25. Labbé, N, Parent, S, Villemur, R (2003) Addition of trace metals increases denitrification rate in closed marine systems. Water Res 37: 914-920

26. Lane, DJ (1991) 16S/23S rRNA sequencing. In: Stackbrandt, E, Goodfellow, M (Eds.) Nucleic acid techniques in bacterial systematics. Chichester, John Wiley and Sons, UK, pp 115-175

27. Lee, NM, Welander, T (1996) The effect of different carbon sources on respiratory denitrification in biological wastewater treatment. J Ferment Bioeng 82: 277-285

28. Lemmer, H, Zaglauer, A, Neef, A, Meier, H, Amann, R (1997) Denitrification in a methanol-fed fixed-bed reactor. Part 2: composition and ecology of the bacterial community in the biofilms. Water Res 31: 1903-1908

29. Leonard, N, Blancheton, JP, Guiraud, JP (2000) Populations of heterotrophic bacteria in an experimental recirculating aquaculture system. Aquac Eng 22: 109-120

30. Loukidou, MX, Zouboulis, AI (2001) Comparison of two biological treatment processes using attached-growth biomass for sanitary landfill leachate treatment. Environ Pollut 111: 273-281

31. Metcalf \& Eddy Inc. (Eds) (2003) Wastewater Engineering. Treatment and Reuse. 4th Ed. McGraw-Hill International Editions. Civil Engineering Series, $1334 \mathrm{p}$

32. Michaud, L, Blancheton, JP, Bruni, V, Piedrahita, R (2006) Effect of particulate organic carbon on heterotrophic bacterial populations and nitrification efficiency in biological filters. Aquac Eng 34: 224-233

33. Munsch, P, Alatossava, T, Marttinen, N, Meyer, JM, Christen, R, Gardan, L (2002) Pseudomonas costantinii sp. nov., another causal agent of brown blotch disease, isolated from cultivated mushroom sporophores in Finland. Int J Syst Evol Microbiol 52: 1973-1983

34. Pillay, TVR (1992) Aquaculture and Environment. Fishing News Books, Oxford, England, 189 p

35. Pirttilä, AM, Laukkanen, H, Pospiech, H, Myllylä, R, Hohtola, A (2000) Detection of intracellular bacteria in the buds of Scotch pine (Pinus sylvestris L.) by in situ hybridization. Appl Environ Microbiol 66: 3073-3077

36. Prescott, LM, Harley, JP, Klein, DA (2002) Microbiology, 5th Ed. McGraw-Hill, Inc., USA, $1026 \mathrm{p}$

37. Rhee, S-K, Lee, GM, Yoon, JH, Park, Y-H, Bae, H-S, Lee, S-T (1997) Anaerobic and aerobic degradation of pyridine by a newly isolated denitrifying bacterium. Appl Environ Microbiol 63: 2578-2585

38. Riis, V, Miethe, D, Babel, W (2003) Formate-stimulated oxidation of methanol by Pseudomonas putida 9816. Biosci Biotechnol Biochem 67: 684-690

39. Roca, C, Olsson, L (2001) Dynamic responses of Pseudomonas fluorescens DF57 to nitrogen or carbon source addition. J Biotechnol 86: 39-50

40. Tal, Y, Watts, JEM, Schreier, SB, Sowers, KR, Schreier, HJ (2003) Characterization of the microbial community and nitrogen transformation processes associated with moving bed bioreactors in a closed recirculated mariculture system. Aquaculture 215: 187-202

41. Tryfinopoulou, P, Tsakalidou, E, Nychas, G-JE (2002) Characterization of Pseudomonas spp. associated with spoilage of gilt-head sea bream stored under various conditions. Appl Environ Microbiol 68: 65-72 
42. Van Rijn, J (1996) The potential for integrated biological treatment systems in recirculating fish culture-a review. Aquaculture 139: 181-201

43. Van Rijn, J, Tal, Y, Barak, Y (1996) Influence of volatile fatty acids on nitrite accumulation by a Pseudomonas stutzeri strain isolated from a denitrifying fluidized bed reactor. Appl Environ Microbiol 62: $2615-2620$
44. Van Rijn, J, Tal, Y, Schreier, HJ (2006) Denitrification in recirculating systems: theory and applications. Aquac Eng 34: 364-376

45. Verhille, S, Baida, N, Dabboussi, F, Hamze, M, Izard, D, Leclerc, H (1999) Pseudomonas gessardii sp. nov. and Pseudomonas migulae sp.nov., two new species from natural mineral waters. Int J Syst Bacteriol 4: 1559-1572 